\title{
In vivo clearance and elimination of nine marker substances during hemofiltration with different membranes
}

\author{
B.K. KRÄMER', A. PICKERT' , C. HOHMANN', H.M. LIEBICH ${ }^{2}$, G.A. MÜLLER ${ }^{1}$, M. HABLITZEL', T. RISLER \\ 1 Section of Nephrology and Hypertension, III Department of Medicine \\ 2 IV Department of Medicine and Clinical Chemistry, University of Tübingen, Tübingen - Germany
}

\begin{abstract}
The handling of low, middle and high molecular weight markers was examined in seven stable dialysis patients during hemofiltration with different membranes. Four membranes were examined in a randomized, crossover order (polysulfone, polyamide, AN69 polyacrylonitrile, Asahi polyacrylonitrile) by measuring plasma and dialysate concentrations of phosphate, creatinine, vitamin $B_{12}, \beta_{2}$-microglobulin, furanic acid, hippuric acid, retinolbinding protein, alpha-1-antitrypsin, and albumin. Sieving coefficients and plasma clearances of $\beta_{2}$-microglobulin or retinol-binding protein were markedly or slightly lower during hemofiltration with the Asahi polyacrylonitrile membrane than with the other membranes (highest removal with polysulfone/AN69 polyacrylonitrile membranes). No differences of obvious clinical relevance could be seen between the four membranes. A high $\beta_{2}$ microglobulin removal rate might be important to prevent dialysis-associated amyloidosis. (Int J Artif Organs 1992; 15: 408-12)
\end{abstract}

KEY WORDS: Hemofiltration, AN69 polyacrylonitrile, Asahi polyacrylonitrile, polysulfone, polyamide

\section{INTRODUCTION}

Controversies regarding the role of uremic toxins, e.g. middle molecules, in morbidity and mortality of patients with end-stage renal disease (ESRD) still persist $(1,2)$, but have stimulated the development of membranes that remove these middle molecules. Since the identification of $\beta_{2}$-microglobulin as the major component in dialysis-associated amyloidosis $(3,4)$, the removal of this protein during hemodialysis, hemofiltration and peritoneal dialysis has been widely studied (5-12).

$\beta_{2}$-microglobulin is removed better during hemodialysis with synthetic membranes (e.g. AN69 polyacrylonitrile, polysulfone), than with cellulosic membranes $(12-14,27,28)$.

The present study compared characteristics of four different membranes in vivo with regard to parameters that serve to calculate clearances and elimination of markers mainly dependent on the size of the molecule (e.g. phosphate, creatinine, alpha-1-antitrypsin, albumin) and of markers more dependent on the protein binding and/or of potential influence as uremic toxins (e.g. $\beta_{2}$-microglobulin, 3-carboxy-4-methyl-5propyl-2-furanpropionic acid = furanic acid, hippuric acid, vitamin $B_{12}$, retinol-binding protein).

\section{PATIENTS AND METHODS}

Seven stable patients with ESRD were studied after giving their informed consent. Their mean age was 54 \pm 11 years (36-70) and they had been on chronic hemodialysis treatment for $51 \pm 57$ months (7-144); the etiology of the renal failure was diabetes mellitus $(n=2)$, crescentic glomerulonephritis $(n=1)$, mesangio- 
proliferative glomerulonephritis $(n=1)$, interstitial nephritis $(n=1)$, chronic glomerulonephritis $(n=1)$, unknown $(n=1)$. Post-dilution hemofiltration ( $3 \mathrm{~h}$ duration; $18 \mathrm{~L}$ of substitution fluid; $250 \mathrm{ml} / \mathrm{min}$ blood flow; $300 \mathrm{~mm}$ $\mathrm{Hg}$ transmembrane pressure; AFG 04 machine, DialyseTechnik, Rheinstetten-Forchheim, Germany) was performed using four different membranes [Filtral ${ }^{\mathrm{R}} 16$ (Hospal Medizintechnik GmBH, Nürnberg, Germany, AN69 polyacrylonitrile membrane, $1.7 \mathrm{~m}^{2}$ surface), $\mathrm{HF}$ ${ }^{80 R}$ (Fresenius AG, Bad Homburg, Germany, polysulfone membrane, $1.8 \mathrm{~m}^{2}$ surface), $\mathrm{FH} 88^{\mathrm{R}}$ (Gambro $A B$, Lund, Sweden, polyamide membrane, $2.0 \mathrm{~m}^{2}$

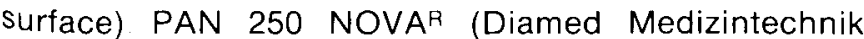
$\mathrm{GmbH}$, Köln, Germany, Asahi polyacrylonitrile membrane, $\left.1.8 \mathrm{~m}^{2}\right)$ ] in a randomized order in all patients. Three hemofiltration procedures were done with each membrane (six patients could be studied almost completely with all membranes, whereas one patient was studied incompletely).

Blood samples from the arterial and venous lines and samples of filtrate were obtained $15 \mathrm{~min}, 1 \mathrm{~h}, 2 \mathrm{~h}$, and $3 \mathrm{~h}$ after the start of the hemofiltration procedure. Hippuric acid and furanic acid were measured by HPLC (15), vitamin $B_{12}$ by a radioreceptor test ( $F a$. Biermann, Bad Nauheim, Germany) modified to reach a detection limit of $10 \mathrm{pg} / \mathrm{ml}$, and albumin, alpha-1antitrypsin, and retinol-binding protein by nephelometry (Behring-Nephelometer-Analyzer, Behringwerke, Marburg, Germany) using antisera from Behring and modifications in the assay systems in order to reach detection limits of $0.2 \mathrm{mg} / \mathrm{dl}, 0.5 \mathrm{mg} / \mathrm{dl}$, and $0.12 \mathrm{mg} /$ $d$, respectively. $\beta_{2}$-microglobulin was measured by a commercially available Elisa (SynelisaBETA-2-MIKROGLOBULINR, Elias Medizintechnik GmbH, Freiburg, Germany) with a detection limit of $0.05 \mathrm{mg} / \mathrm{dl}$. Creatinine and phosphate were measured by routine laboratory methods.

Statistical analysis was done by Student's t-test and $p$ values $<0.05$ were considered statistically significant; data are given as mean $\pm \mathrm{SD}$.

The sieving coefficient of a marker was calculated as

Sieving coefficient $=$

$\frac{2 \times C \text { filtrate }}{C \text { arterial }+C \text { venous }}$

Where $\mathrm{C}$ stands for concentration of the marker in either the filtrate or arterial or venous plasma.
The plasma clearance of a marker was calculated as sieving coefficient $x$ ultrafiltration rate. If the concentration of a marker in the filtrate was below the detection limit of the assay, the lowest measurable concentration was used for calculation of the sieving coefficient and consecutively of the plasma clearance. These sieving coefficients and plasma clearances are the maximum possible values and thus might cause some overestimation.

\section{RESULTS}

Mean sieving coefficients of phosphate, creatinine, $\beta_{2}$-microglobulin, hippuric acid, and retinol-binding protein are given in Table 1 . The $\beta_{2}$-microglobulin sieving coefficient was significantly lower $(p<0.001)$ during hemofiltration with the Asahi polyacrylonitrile membrane than with the other membranes and was highest with the AN69 and polysulfone membranes. A similar pattern was found for retinol-binding protein, removal being highest with the polysulfone membrane. Differences between membranes were only slight for creatinine and hippuric acid. Sieving coefficients were $\leq 0.02$ for vitamin $B_{12}$ and furanic acid, $\leq 0.004$ for alpha-1-antitrypsin, and $\leq 0.001$ for albumin.

Plasma clearances of phosphate, creatinine, $\beta_{2}$ microglobulin, hippuric acid, and retinol-binding protein are given in Table II. Plasma clearances of $\beta_{2}-$ microglobulin and retinol-binding protein were significantly lower with the Asahi polyacrylonitrile membrane than with the other membranes. Plasma clearances for the AN69 membrane tended to be lower for the remaining markers. Plasma clearances were $\leq 1.5 \mathrm{ml}$ / min for vitamin $B_{12}, \leq 1.0 \mathrm{ml} / \mathrm{min}$ for alpha-1-antitrypsin and furanic acid, and $\leq 0.2 \mathrm{ml} / \mathrm{min}$ for albumin.

\section{DISCUSSION}

Synthetic high-flux membranes used in a convective mode were studied with regard to marker substances with molecular masses ranging from 98 to 66500 Daltons. All studies were done in vivo because of the well-known effect of secondary membrane formation, due to contact of the membrane with blood, with the subsequent decrease of sieving coefficients not detectable in vitro (16). 
TABLE I - MEAN SIEVING COEFFICIENTS ( \pm SD) DURING HEMOFILTRATION WITH FOUR DIFFERENT MEMBRANES

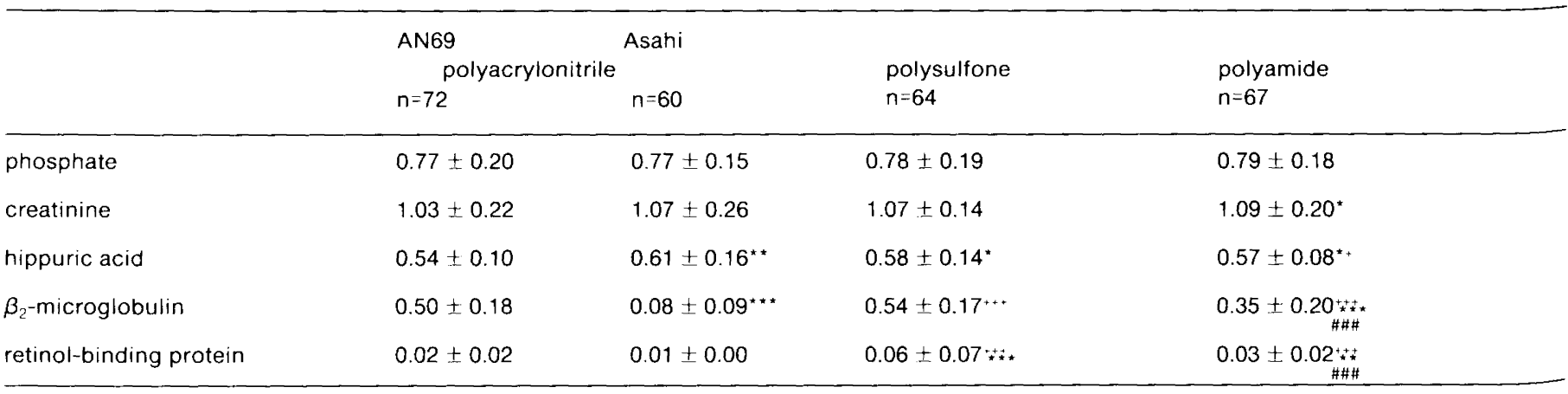

*: in comparison with AN69 membrane; ": in comparison with Asahi membrane, \#: in comparison with polysulfone membrane $p<0.05,1$ symbol; $p<0.01,2$ symbols; $p<0.001,3$ symbols.

TABLE II - PLASMA CLEARANCE (ml/min) OF DIFFERENT MARKERS DURING HEMOFILTRATION WITH FOUR DIFFERENT MEMBRANES (mean $\pm \mathrm{SD}$ )

\begin{tabular}{|c|c|c|c|c|c|}
\hline & & AN69 & Asahi & polysulfone & polyamide \\
\hline & & po & & & \\
\hline & & $n=72$ & $n=60$ & $n=64$ & $n=67$ \\
\hline & $15 \mathrm{~min}$ & 74 & 82 & 82 & 86 \\
\hline & $1 \mathrm{~h}$ & 69 & 77 & 80 & 78 \\
\hline phosphate & $2 \mathrm{~h}$ & 70 & 72 & 74 & 71 \\
\hline & $3 h$ & 52 & 60 & 69 & 73 \\
\hline & mean & $66 \pm 23$ & $73 \pm 20^{*}$ & $76 \pm 24^{\star *}$ & $77 \pm 22^{* \star}$ \\
\hline & $15 \mathrm{~min}$ & 100 & 109 & 112 & 117 \\
\hline & $1 \mathrm{~h}$ & 93 & 103 & 109 & 107 \\
\hline creatinine & $2 \mathrm{~h}$ & 94 & 93 & 102 & 98 \\
\hline & $3 h$ & 71 & 96 & 90 & 92 \\
\hline & mean & $90 \pm 30$ & $101 \pm 30^{*}$ & $105 \pm 25^{\star *}$ & $105 \pm 23^{* *}$ \\
\hline & $15 \mathrm{~min}$ & 54 & 67 & 59 & 66 \\
\hline & $1 \mathrm{~h}$ & 50 & 63 & 58 & 59 \\
\hline hippuric acid & $2 \mathrm{~h}$ & 47 & 57 & 56 & 52 \\
\hline & $3 \mathrm{~h}$ & 37 & 48 & 51 & 45 \\
\hline & mean & $47 \pm 15$ & $59 \pm 22^{* \star \star}$ & $56 \pm 16^{* * *}$ & $56 \pm 15^{\star \star \star}$ \\
\hline & $15 \mathrm{~min}$ & 34 & 7 & 63 & 27 \\
\hline & $1 \mathrm{~h}$ & 49 & 9 & 60 & 31 \\
\hline$\beta_{2}$-microglobulin & $2 \mathrm{~h}$ & 55 & 8 & 52 & 36 \\
\hline & $3 \mathrm{~h}$ & 37 & 7 & 41 & 39 \\
\hline & mean & $44 \pm 20$ & $8 \pm 8^{* * *}$ & $54 \pm 22$ & $33 \pm 21$ \\
\hline & $15 \min$ & 3 & 1 & 11 & 3 \\
\hline & $1 \mathrm{~h}$ & 2 & 1 & 4 & 3 \\
\hline retinol-binding protein & $2 \mathrm{~h}$ & 2 & 1 & 4 & 3 \\
\hline & $3 \mathrm{~h}$ & 1 & 1 & 3 & 2 \\
\hline & mean & $2 \pm 2$ & $1 \pm 1^{\star * *}$ & $6 \pm 8$ & 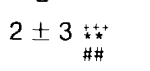 \\
\hline
\end{tabular}

*: in comparison with AN69 membrane; ": in comparison with Asahi membrane, \#: in comparison with polysulfone membrane $p<0.05,1$ symbol; $p<0.01,2$ symbols; $p<0.001,3$ symbols. 
Sieving coefficients and plasma clearances of low molecular mass markers (98-240 Daltons) do not markedly differ with the various membranes, provided that the molecules are sufficiently soluble as free substances in plasma. This is demonstrated by the high values for phosphate and creatinine, no noteworthy removal of furanic acid due to $>99 \%$ protein binding and an intermediate response of hippuric acid partly due to the $40-50 \%$ protein binding (Tabs. I and II).

The removal of low molecular markers seemed to be somewhat lower with the AN69 membrane. Phosphate, creatinine and hippuric acid plasma clearances decreased by about $10-20 \%$ during three hours of hemofiltration with no obvious difference between membranes. These results are in accordance with the literature, but most authors either investigated only one or two membranes or a limited number of marker substances (only creatinine was included in the majority of reports) $(12,17-19)$. The role of hippuric acid and furanic acid as uremic toxins has not yet been established, but markedly elevated plasma levels have been reported $(15,20,21)$. Schoots et al. (21) reported that hippuric acid is an independent parameter that correlates closely with residual renal function.

With the exception of the markedly lower removal of $\beta_{2}$-microglobulin and retinol-binding protein by the polyacrylonitrile Asahi membrane (and the better results with the polysulfone and AN69 membranes), the sieving coefficients and plasma clearances of middle molecular mass markers (1355-21000 Daltons) were not different with the membranes tested. Low removal rates of vitamin $B_{12}$ and retinol-binding protein are due to protein binding (e.g. transcobalamin, prealbumin), and are in accordance with previous reports $(16,22,23)$. No appreciable removal of vitamin $B_{12}$ was seen despite its low molecular mass (1355 Daltons), and this makes vitamin $B_{12}$ a useful marker only in vitro. Sieving coefficients of $\beta_{2}$-microglobulin range from about $0.4-0.8(12,16,17,19,22-24)$ and tend to decrease moderately to markedly $(16,22,23)$ or remain constant during hemofiltration (24). Interestingly, Asahi polyacrylonitrile (PAN series) seems to be almost impermeable to $\beta_{2}$-microglobulin, in contrast to AN69 polyacrylonitrile $(16,22,26)$, which seems to have a high initial absorption of $\beta_{2}$-micro- globulin $(24,25,27,28)$. As reported elsewhere the high molecular mass markers albumin and alpha-1antitrypsin were not removed in substantial amounts in the present study $(16,19,22,23)$; minor removal of alpha-1-antitrypsin and albumin has been demonstrated during the very first few minutes (23) before secondary membranes formed, but in the present study the first measurements were made after 15 minutes.

In conclusion, with the exception of the very low removal of $\beta_{2}$-microglobulin and to a minor extent of retinol-binding protein with the Asahi polyacrylonitrile membrane, the other differences between the synthetic membranes examined with regard to removal of marker substances with molecular masses from about 100 to about 67000 Daltons seem to be of little clinical relevance.

Reprint requests to:

Bernhard Krämer, MD

III Department of Medicine

University of Tübingen

Otfried-Müller-Str. 10

W-7400 Tübingen, Germany

\section{REFERENCES}

1. Bergström J, Fürst $P$, Zimmerman L. Uremic middle molecules exist and are biologically active. Clin Nephrol 1979; 11: 229-38.

2. Navarro J, Contreras $P$, Touraine JL, Freyria AM, Later R, Traeger J. Are "middle molecules" responsible for toxic phenomena in chronic renal failure? Nephron 1982; 32: 301-7.

3. Gejyo F, Yamada T, Odani S, et al. A new form of amyloid protein associated with chronic hemodialysis was identified as $\beta_{2}$-microglobulin. Biochem Biophys Res Comm 1985; 129: 701-6.

4. Gorevic PD, Casey TT, Stone WJ, DiRaimondo CR, Prelli FC, Frangione B. Beta-2-microglobulin is an amyloidogenic protein in man. J Clin Invest 1985; 76 : 2425-9.

5. Blumberg $A$, Bürgi $W$. Behaviour of $\beta_{2}$-microglobulin in patients with chronic renal failure undergoing hemodi- 
alysis, hemodiafiltration and continuous ambulatory peritoneal dialysis (CAPD). Clin Nephrol 1987; 27: 245-9.

6. Flöge J, Granolleras C, Bingel $M$, et al. $\beta_{2}$-microglobulin kinetics during haemodialysis and haemofiltration. Nephrol Dial Transplant 1987; 1: 223-8.

7. Kaiser JP, Hagemann J, von Herrath D, Schäfer $K$. Different handling of beta ${ }_{2}$-microglobulin during hemodialysis and hemofiltration. Nephron 1988; 48; 132-5.

8. Mayer G, Thum J, Woloszuk W, Graf H. Beta-2microglobulin in hemodialysis patients. Am J Nephrol 1988; 8: 280-4.

9. Tielemans $C$, Dratwa $M$, Bergmann $P$, et al. Continuous ambulatory peritoneal dialysis vs haemodialysis: A lesser risk of amyloidosis? Nephrol Dial Transplant 1988; 3 : $291-4$.

10. Zingraff $J$, Beyne $P$, Urena $P$, et al. Influence of haemodialysis membranes on $\beta_{2}$-microglobulin kinetics: in vivo and in vitro studies. Nephrol Dial Transplant 1988; 3: 284-90.

11. Stone WJ, Hakim RM. Beta-2-microglobulin amyloidosis in long-term dialysis patients. Am $J$ Nephrol 1989; 9: 177-83.

12. Streicher $E$, Schneider $H$. Polysulphone membrane mimicking human glomerular basement membrane. Lancet 1983; II: 1136.

13. Hauglustaine D, Waer M, Michielsen P, Goebels J, Vandeputte $M$. Haemodialysis membranes, serum $\beta_{2^{-}}$ microglobulin, and dialysis amyloidosis. Lancet 1986; I: 1211-2.

14. Chanard J, Toupance $O$, Lavaud S, Jaisser F, Gillery P. Serum $\beta_{2}$-microglobulin and extracellular fluid volume during haemodialysis. Nephrol Dial Transplant 1989; 4: 549-54.

15. Pickert A, Bäuerle A, Liebich HM. Determination of hippuric acid and furanic acid in serum of dialysis patients and control persons by high-performance liquid chromatography. J Chromatogr 1989; 495: 95-104.

16. Röckel A, Gilge U, Liewald A, Heidland A. Elimination of low molecular weight proteins during hemofiltration. Int J Artif Organs 1982; 6; 307-11.

17. Schneider $\mathrm{H}$, Streicher $\mathrm{E}$. Mass transfer characterization of a new polysulfone membrane. Artif Organs 1985; 9 : 180-3

18. Schoots AC, Peeters JAG, Gerlag PGG. Effect of hemodialysis on serum concentrations of HPLC-ana- lyzed accumulating solutes in uremia. Nephron 1989; 53: 208-17.

19. Wizemann V, Velcovsky HG, Bleyl H, Brüning $S$, Schütterle $\mathrm{G}$. Removal of hormones by hemofiltration and hemodialysis with a highly permeable polysulfone membrane. Contr Nephrol 1985; 46: 61-8.

20. Liebich HM, Risler T, Fischer U, Rapp K, Tetschner B, Eggstein M. Gas chromatographic determination of hippuric acid and a furan-carboxylic acid in plasma of patients with kidney diseases. J Chromatogr 1987; 399: 291-4.

21. Schoots AC, Dijkstra JB, Ringoir SMG, Vanholder R, Cramers CA. Are the classical markers sufficient to describe uremic solute accumulation in dialyzed patients? Hippurates reconsidered. Clin Chem 1988; 34: 1022-9

22. Röckel A, Abdelhamid S, Fiegel P, Walb D. Elimination of low molecular weight proteins with high flux membranes. Contr Nephrol 1985; 46: 69-74.

23. Röckel A, Hertel J, Fiegel P, Abdelhamid S, Panitz N, Walb D. Permeability and secondary membrane formation of a high flux polysulfone hemofilter. Kidney Int 1986; 30: 429-32.

24. Floege J, Granolleras $C$, Deschodt $G$, et al. High-flux synthetic versus cellulosic membranes for $\beta_{2}$-microglobulin removal during hemodialysis, hemodiafiltration and hemofiltration. Nephrol Dial Transplant 1989; 4: 653-7.

25. Floege J, Wilks $M$, Shaldon S, Koch KM, Smeby LC $\beta_{2}$-microglobulin kinetics during haemofiltration. Nephrol Dial Transplant 1988; 3: 784-9.

26. Marsen T, Hönig R, Schad S, Barth C, Pollok M, Baldamus CA. How to interpret intratreatment changes in plasma beta-2-microglobulin concentrations. Contrib Nephrol 1989; 74: 147-52.

27. Klinke B, Röckel A, Abdelhamid S, Fiegel P, Walb D. Transmembranous transport and adsorption of beta-2microglobulin during hemodialysis using polysulfone, polyacrylonitrile, polymethyl-methacrylate and cuprammonium rayon membranes. Int $\mathrm{J}$ Artif Organs 1989; 12 : 697-702.

28. Martin-Malo A, Mallol J, Castillo D, et al. Factors affecting $\beta_{2}$-microglobulin plasma concentration during hemodialysis. Int J Artif Organs 1989; 12: 509-14. 